\title{
THE IMAGE MAINTENANCE OF PURWAKARTA REGENT THROUGH GEMPUNGAN ACTIVITIES IN PURWAKARTA REGENCY
}

\section{PENCITRAAN BUPATI PURWAKARTA MELALUI KEGIATAN GEMPUNGAN DI KABUPATEN PURWAKARTA}

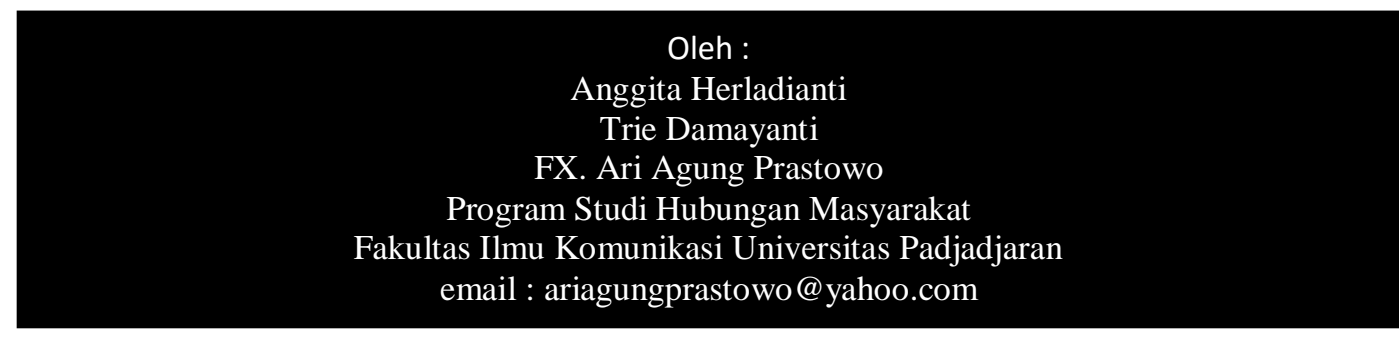

Abstract, Gempungan is an implementation of Purwakarta government program contained in "Salapan Lengkah Ngawangun Nagri Raharja". In general, this activity is a form of service to the community that is "proactive", where services are provided in the form of administrative services of residence (KTP, KK, Birth Certificate, Book of Marriage and others), health services, blood donor, family planning services, mass circumcision, as well as input from religious leaders, community leaders and citizens as a whole. This activity is done once a week rotating in 192 villages in Purwakarta regency. The event ended with the "Ngahajatan urang overtime" that was held at night, filled with arts and entertainment events which were dedicated to the community. This study aims to find out about the image maintenance of Purwakarta Regent, Dedi Mulyadi, through Gempungan activities In Purwakarta regency. This research was a qualitative research with explorative case study approach. The data in this study were obtained through direct observation, interviews, and review of the literature Regent Dedi Mulyadi in order to fulfill people's aspirations that had not been fulfilled by Purwakarta Government. In addition, with Gempungan activities, Regent Dedi Mulyadi was able to know more about the condition and needs of the community so that the programs created by the local government would be more effective and efficient. The community gave positive response on Gempungan activities and the majority also stated that the Regent Dedi Mulyadi was a figure that highly concerned on the public welfare and was one of the best Regents Purwakarta ever owned.

Abstrak, Gempungan adalah implementasi dari program pemerintah purwakarta yang tertuang dalam"Salapan Lengkah Ngawangun Nagri Raharja”. Secara umum kegiatan ini merupakan bentuk pelayanan kepada masyarakat yang bersifat "jemput bola", dimana pelayanan yang diberikan berupa pelayanan administrasi kependudukan (KTP, KK, Akte Kelahiran, Buku Nikah dan lainnya), pelayanan kesehatan, donor darah, pelayanan KB, khitanan massal, serta masukan dari tokoh agama, tokoh masyarakat serta warga secara keseluruhan. Kegiatan ini dilakukan seminggu sekali berputar di 192 desa dan kelurahan di wilayah kabupaten Purwakarta. Kegiatan ini diakhiri dengan acara "Ngahajatan urang lembur" yang dilaksanakan pada malam hari, diisi dengan acara kesenian serta hiburan yang khusus dipersembahkan kepada warga masyarakat. Penelitian ini bertujuan untuk mengetahui bagaimana pencitraan Bupati Purwakarta yaitu Dedi Mulyadi melalui kegiatan Gempungan Di Kabupaten Purwakarta. Metode penelitian yang digunakan dalam penelitian mengenai pencitraan Bupati Purwakarta melalui kegiatan Gempungan Di Kabupaten Purwakarta adalah metode penelitian kualitatif dengan pendekatan studi kasus eksploratif. Data dalam penelitian ini diperoleh melalui observasi langsung, wawancara mendalam, dan telaah pustaka dan dokumen. Hasil penelitian menunjukkan bahwa kegiatan Gempungan dibuat oleh Bupati Dedi Mulyadi karena adanya aspirasi masyarakat yang belum sempat dipenuhi oleh Pemkab Purwakarta. Selain itu dengan adanya kegiatan Gempungan, Bupati 
Dedi Mulyadi lebih dapat mengetahui seperti apa kondisi dan kebutuhan masyarakat sehingga program-program yang diciptakan oleh Pemkab akan lebih efektif dan efisien. Masyarakat pun menanggapi kegiatan Gempungan ini sangat positif, dan mayoritas masyarakat juga menyatakan bahwa Bupati Dedi Mulyadi merupakan sosok yang sangat mempedulikan kesejahteraan masyarakat dan merupakan salah satu Bupati terbaik yang pernah dimiliki Purwakarta.

Kata Kunci: pencitraan, kegiatan Gempungan

\section{A. PENDAhuluan}

Bupati Purwakarta, Dedi Mulyadi merupakan salah seorang Bupati yang memiliki banyak sekali program pemerintah yang ingin diterapkannya di Purwakarta. Sebelum menjadi Bupati Purwakarta periode 2008-2013, Dedi Mulyadi melakukan sebuah kegiatan dengan cara mendekatkan diri dengan masyarakat, terjun langsung dan melihat secara jelas apa saja yang menjadi kebutuhan dan keinginan masyarakat Purwakarta, kegiatan tersebut lebih dikenal sebagai "Gempungan Di Buruan Urang Lembur".

Gempungan ini sendiri menurut salah satu aparat Pemkab Purwakarta yang diwawacarai penulis merupakan salah satu implementasi dari program pemerintah Kabupaten Purwakarta yang tertuang dalam "Salapan Lengkah Ngawangun Nagri Raharja”. Secara umum kegiatan ini merupakan bentuk pelayanan kepada masyarakat yang bersifat "jemput bola", dimana pelayanan yang diberikan berupa pelayanan administrasi kependudukan (KTP, KK, Akte Kelahiran, Buku Nikah dan lainnya), pelayanan kesehatan, donor darah, pelayanan $\mathrm{KB}$, khitanan massal, serta masukan dari tokoh agama, tokoh masyarakat serta warga secara keseluruhan. Kegiatan ini dilakukan seminggu sekali berputar di 192 desa dan kelurahan di wilayah kabupaten Purwakarta. Kegiatan ini diakhiri dengan acara "Ngahajatan urang lembur" yang dilaksanakan pada malam hari, diisi dengan acara kesenian serta hiburan yang khusus dipersembahkan kepada warga masyarakat.

Kegiatan "Gempungan" seperti yang dilakukan oleh Dedi Mulyadi ini juga dilakukan oleh Gubernur DKI Jakarta saat ini yaitu Joko Widodo atau lebih dikenal dengan Jokowi pada saat Jokowi masih menjabat sebagai walikota Solo namun dikenal dengan nama "Blusukan". Program-program Jokowi dalam Blusukan tersebut pun hampir sama dengan Gempungan milik DediMulyadi, hanya saja ketika Jokowi 
menjabat sebagai Gubernur DKI Jakarta, Blusukan menjadi kurang populer karena oleh segelintir orang yang kontra dengan Jokowi mengatakan bahwa Blusukan hanyalah strategi kampanye Jokowi semata, dan keberhasilan Jokowi menduduki jabatan Gubernur tersebut juga bukan dikarenakan popularitasnya karena Blusukan.

Berbeda halnya dengan Gempungan yang dilakukan oleh Dedi Mulyadi di Purwakarta yang notabene kotanya lebih kecil dibandingkan Jakarta sehingga cakupan kegiatan tersebut pun bisa hampir menyeluruh. Bahkan Melansir sebuah lembaga survei bahwa tingkat pengenalan dan kesukaan masyarakat Purwakarta terhadap Dedi Mulyadi sebagai Bupati Purwakarta peride 2008-2013 diangka 90 persen hampir mendekati 100 persen. Masyarakat mengenal dan menyukai gaya kepemimpinan Dedi dengan program 'Gempungan' yang selama 5 tahun kepemimpinannya kerap menyambangi masyarakatnya di 17 kecamatan.

Namun demikian, meskipun pelaksanaan "Gempungan" ini dinilai positif dan bermanfaat bagi masyarakat Kabupaten Purwakarta, ternyata tidak semua masyarakat pun pro terhadap Bupati. Seperti hasil wawancara prapenelitian terhadap beberapa masyarakat yang menyatakan bahwa Bupati Dedi Mulyadi rajin melakukan Gempungan dikarenakan beliau mempunyai keinginan untuk tetap menjabat sebagai Bupati semata, atau dengan kata lain hanya sebatas meningkatkan reputasi dan citra di mata masyarakat Purwakarta. Selain itu berdasarkan observasi penulis serta wawancara pra-penelitian dengan beberapa warga Purwakarta, ada beberapa konsekuensi dari penerapan politik pencitraan ini: pertama, masyarakat selalu menemukan ketidaksesuaian antara ucapan dan tindakan, dan ketimpangan antara janjijanji dan pelaksanaannya. Kedua, ada proses manipulasi data, khususnya statistik, yang sangat menonjol dan sistematis, seperti data soal angka kemiskinan, pengangguran, dan lainlain. Ketiga, aktor politik seringkali terlihat lambat dalam merespon "situasi genting", begitu banyak pertimbangan (soal image), dan tidak pemberani dalam mengambil-alih persoalan berat. Keempat, suka menyuap "mulut kaum yang lapar" dengan program 
belas kasihan yang sangat terbatas, tentative, dan tidak kontinyu.

Perbedaan-perbedaan tersebut yang kemudian memunculkan tanda tanya bagi masyarakat, apakah kegiatan "Gempungan Di Buruan Urang Lembur" yang dilakukan oleh Bupati Purwakarta Bapak Dedi Mulyadi hanyalah merupakan sebuah pencitraan yang juga bisa dikatakan sebagai suatu kampanye "terselubung" mengingat pada tahun-tahun kedepan ini akan dilakukan pemilukada lagi, ataukah kegiatan ini benar-benar murni keinginan dari hati sang Bupati untuk mendekatkan diri kepada masyarakat dan menjadikan masyarakat Purwakarta menjadi lebih sejahtera dan makmur dibandingkan sebelumnya.

Dua hal yang pro dan kontra tersebut yang kemudian menjadi fenomena yang menarik untuk diangkat oleh penulis dalam penelitian ini. Di satu pihak adanya kegiatan "Gempungan Di Buruan Urang Lembur" dianggap sangat efektif untuk memajukan masyarakat Purwakarta karena sang Bupati jadi lebih mengetahui apa saja permasalahanpermasalahan yang dihadapi masyarakat, akan tetapi di pihak lain muncul pemberitaan bahwa kegiatan tersebut bukanlah dilakukan karena kepentingan masyarakat tapi karena kepentingan pribadi sang Bupati demi pencitraannya.

Berkaitan dengan hal tersebut, perilaku manusia sebagai bagian dari sistem sosial ini tak lain adalah juga untuk menunjukkan citra diri, sebagai salah satu bentuk upaya untuk dapat diterima di lingkungannya. Hal ini menunjukkan bahwa citra bukanlah milik eksklusif sebuah perusahaan, organisasi, maupun instansi formal yang diatur oleh suatu manajemen, melainkan juga manusia sebagai makhluk sosial. Berkaitan dengan penelitian ini, kegiatan gempungan yang diadakan semenjak diangkatnya Dedi Mulyadi sebagai Bupati Kabupaten Purwakarta, setidaknya bertujuan untuk membentuk citra Dedi Mulyadi sebagai Bupati yang memperdulikan kesejahteraan masyarakat Purwakarta.

Eksistensi Bupati Purwakarta apabila dipandang melalui kacamata public relations, Bupati Purwakarta memiliki citra di mata masyarakat yang merupakan publik eksternal dari pihak Bupati Purwakarta. Masyarakat 
menerima pengetahuan dan informasiinformasi mengenai jejak rekam Bupati Purwakarta dan kemudian masyarakat mencitrakan Bupati Purwakarta karena pengetahuan dan perilaku anggota Bupati Purwakarta sebagai stimulus.

Perilaku mempunyai potensi komunikasi dan komunikasi sebagai eksistensi diri, maka dapat dikatakan perilaku Bupati Purwakarta merupakan suatu komunikasi sebagai bukti eksistensi diri mereka dalam lingkup kemasyarakatan. Berdasar atas keilmuan public relations yang peneliti pelajari, peneliti mencoba untuk meneliti pencitraan Bupati Purwakarta, yaitu bagaimana pencitraan Bupati Purwakarta berdasarkan penjelasan dan penuturan anggota masyarakat, maupun pihak Bupatiberdasar atas pengetahuan dan perkembangannya.

Penulis akan memaparkan hasil penelitian terdahulu yang sejenis, berikut ini adalah penelitian-penelitian sejenis yang memiliki kesamaan dalam metode seperti yang digunakan dalam penelitian dibawah ini.

1. Penelitian sejenis yang menjadi penelitian adalah milik Raja Dony Jaka Umbara, Event Vegetarian
Food Fiesta Dinas Pariwisata dan Kebudayaan Kota Batam. Penelitian ini bertujuan untuk mengetahui bagaimana Dinas Pariwisata dan Kebudayaan Kota Batam menjadikan special event sebagai strategi mereka dalam upaya meningkatkan jumlah kunjungan wisatawan mancanegara yang datang ke Kota Batam.Metode yang digunakan dalam penelitian ini adalah deskriptif dengan data kualitatif. Teknik pengumpulan data yang digunakan adalah wawancara, observasi, serta studi dokumentasi dan pustaka. Hasil dari penelitian ini adalah keberhasilan Kota Batam dalam meningkatkan kunjungan wisatawan mancanegara dengan mengandalkan special event meskipun Batam minim sekali dengan objek wisata. Selain itu melalui special event yang bertajuk Vegetarian Food Fiesta ini Kota Batam mendapat sebutan sebagai "Surga Vegetarian" dari para wisatawan mancanegara. Sedangkan masalah yang dihadapi oleh Dinas Pariwisata dan Kebudayaan Kota Batam adalah 
masalah kegiatan promosi yang disebabkan oleh minimnya dana yang diberikan. Kesimpulan dari hasil penelitian ini adalah Dinas Pariwisata dan Kebudayaan Kota Batam harus lebih maksimal lagi dalam melakukan kegatan promosi agar event Vegetarian Food Fiesta ini dapat berjalan lebih baik lagi kedepannya. Saran yang ingin disampaikan kepada Disbudpar Batam, sebaiknya untuk penyelenggaraan event ini kedepannya harus lebih melakukan kerjasama dengan pemerintah pusat agar anggaran yang diberikan dapat lebih besar lagi jumlahnya sehingga dapat memperlancar proses promosi yang dilakukan oleh Disbudpar Batam.

2. Referensi penelitian kedua adalah Rosy Aprianti Gasong, Event Internationale Tourismus Borse (ITB) Berlin 2013 Sebagai Kegiatan Unggulan Promosi Pariwisata Indonesia. Tujuan dari penelitian ini adalah untuk mengetahui pemahaman pelaksana kegiatan, latar belakang partisipasi dan implementasi kegiatan marketing public relations dalam event ITB Berlin 2013 sebagai salah satu upaya promosi pariwisata Indonesia. Metode yang digunakan dalam penelitian ini adalah metode kualitatif dengan pendekatan studi kasus. Kesimpulan dan hasil penelitian menunjukkan bahwa event ITB Berlin 2013 yang dilakukan tidak hanya sebagai salah satu upaya dari promosi pariwisata tapi juga sebagai upaya investasi jangka panjang terhadap perkembangan pariwisata Indonesia. Latar belakang partisipasi Kemenparekraf melalui event ini ialah untuk mendapatkan citra positif mengenai pariwisata Indonesia terutama di kalangan wisatawan mancanegara. Implementasi kegiatan MPR dalam event ini dilakukan melalui push strategy dalam aktivasi - aktivasi yang dilakukan melalui media publikasi dan juga kegiatan kegiatan lainnya di luar Paviliun Indonesia.

3. Penelitian ketiga adalah Benny Yubiarto, Promosi Seni Budaya dan Pariwisata Jawa Barat Melalui Event "Kemilau Nusantara" di Bandung. 
Edutech, Tahun 15, Vol.15, No.2, Juni 2016

Tujuan dari penelitian ini adalah untuk mengetahui bagaimana promosi seni dan budaya yang dilakukan oleh Dinas Pariwisata Jawa Barat melalui event "Kemilau Nusantara". Hasil penelitian ini menunjukkan bahwa kegiatan promosi seni budaya dan pariwisata Jawa Barat yang dilakukan oleh dinas pariwisata propinsi Jawa Barat merupakan langkah penting dalam meningkatkan citra kepariwisataan daerah Jawa Barat. Penelitian ini berusaha mengetahui bagaimana proses kegiatan promosi tersebut dilakukan dengan dasar kaitannya antara unsur bauran promosi dengan pengaturan kegiatan promosi guna membangun sebuah persepsi yang baik terhadap suatu objek sehingga dapat dipahami dan diterima dengan baik. Setiap pelaksanaan kegiatan promosi diperlukan sebuah strategi yang baik dalam penyusunan rencana rencana kerja mulai dari perencanaan, pengelolaan sumber daya dan bentuk penyampaian pesan sehingga dapat dipersepsi secara utuh oleh khalayak dengan efek yang diharapkan. Dan untuk

$\begin{array}{lcr}\text { mengetahui } & \text { proses } & \text { kegiatan } \\ \text { promosi } & \text { tersebut } & \text { digunakan } \\ \text { metode } & \text { penelitian } & \text { kualitatif } \\ \text { deskriptif. } & & \\ & & \end{array}$

Menurut Frank Jefkins (2003) dalam buku Public Relations, definisi citra dalam konteks humas citra diartikan sebagai "kesan, gambaran, atau impresi yang tepat (sesuai dengan kenyataan) atas sosok keberadaan berbagai kebijakan personil personil atau jasa-jasa dari suatu organisasi atau perusaahaan."

Jefkins (2003) menyebutkan beberapa jenis citra (image). Berikut ini lima jenis citra yang dikemukakan, yakni:

1. Mirror Image (Citra Bayangan). Citra ini melekat pada orang dalam atau anggota-anggota organisasi biasanya adalah pemimpinnya mengenai anggapan pihak luar tentang organisasinya. Dalam kalimat lain, citra bayangan adalah citra yang dianut oleh orang dalam mengenai pandangan luar, terhadap organisasinya. Citra ini seringkali tidak tepat, bahkan hanya sekedar ilusi, sebagai akibat dari tidak memadainya informasi, 
Edutech, Tahun 15, Vol.15, No.2, Juni 2016

pengetahuan ataupun pemahaman yang dimiliki oleh kalangan dalam organisasi itu mengenai pendapat atau pandangan pihak-pihak luar. Dalam situasi yang biasa, sering muncul fantasi semua orang menyukai kita. Hal ini merupakan suatu kecenderungan yang wajar, karena hampir semua orang memang menyukai fantasi. Namun, melalui penelitian yang mendalam mengenai citra akan segera terungkap bahwa citra bayangan itu hampir selalu tidak tepat, atau tidak sesuai dengan kenyataan yang sesungguhnya.

2. Current Image (Citra yang Berlaku). Citra yang berlaku adalah suatu citra atau pandangan yang dianut oleh pihak-pihak luar mengenai suatu organisasi. Citra ini sepenuhnya ditentukan oleh banyak-sedikitnya informasi yang dimiliki oleh mereka yang mempercayainya. Sama halnya dengan citra bayangan, citra yang berlaku tidak selamanya, bahkan jarang, sesuai dengan kenyataan, karena semata - mata terbentuk dari pengalaman atau pengetahuan orang - orang luar yang biasanya serba terbatas. Biasanya pula, citra ni cenderung negatif. Public Relations memang menghadapi dunia yang bersifat memenuhi, penuh prasangka, apatis, dan diwarnai keacuhan yang mudah sekali menimbulkan suatu citra yang tidak adil.

3. Multiple Image (Citra Majemuk). Yaitu adanyaimage yang bermacam-macam dari publiknya terhadap organisasi tertentu yang ditimbulkan oleh mereka yang mewakili organisasi kita dengan tingkah laku yang berbeda-beda atau tidak seirama dengan tujuan atau asas organisasi kita. Jumlah citra yang dimiliki perusahaan boleh dikatakan sama banyaknya dengan jumlah pegawai yang dimilikinya. Untuk menghindari berbagai hal yang tidak diinginkan, variasi citra harus ditekan seminimal mungkin dan citra perusahaan secara keseluruhan harus ditegakkan. Banyak cara untuk melakukan hal itu, antara lain dengan mewajibkan semua karyawan mengenakan pakaian seragam, menyamakan jenis dan warna mobil dinas, simbol, 
lencana, pelatihan staf, bentuk bangunan atau interior toko yang khas, design papan nama toko, dan lain - lain.

\section{Corporate}

Image (Citra

Perusahaan). Apa yang dimaksud dengan citra perusahaan adalah citra dari suatu organisasi secara keseluruhan, jadi bukan sekedar citra atas produk dan pelayanannya. Citra perusahaan ini terbentuk dari banyak hal, seperti sejarah atau riwayat hidup perusahaan yang gemilang, keberhasilan dan stabilitas di bidang keuangan, kualitas produk, keberhasilan ekspor, hubungan industri yang baik, reputasi sebagai pencipta lapangan kerja, kesediaan turut memikul tanggung jawab sosial, dan komitmen mengadakan riset. Marks and Spencer memiliki suatu citra perusahaan yang cemerlang dan sudah memperoleh pengakuan internasional. Suatu citra perusahaan yang positif jelas menunjang usaha PR keuangan. Sebagai contoh, suatu badan usaha yang memiliki citra perusahaan positif pasti lebih mudah menjual sahamnya.
5. Wish Image (Citra Yang Diharapkan). Citra harapan adalah suatu citra yang diinginkan oleh pihak manajemen atau suatu organisasi. Citra yang diharapkan biasanya dirumuskan dan diterapkan untuk sesuatu yang relatif baru, ketika khalayak belum memiliki informasi yang memadai mengenainya. Biasanya citra yang diharapkan itu lebih baik atau lebih menyenangkan daripada citra yang ada; walaupun dalam keadaan tertentu, citra yang terlalu baik juga bisa merepotkan. Namun secara umum, yang disebut sebagai citra harapan itu memang sesuatu yang berkonotasi lebih baik. Sebagai contoh, ketika Gordon Selfridge membuka pasar swalayan di Oxford Street, london, beberapa tahun lampau, ia menghendaki agar orang -orang berpikir bahwa pasar swalayan tersebut merupakan suatu tempat yang cocok untuk berjalan - jalan setiap harinya yakni suatu tempat yang penuh hiburan dan serba menyenangkan, daripada tempat yang membosankan. Citra yang diharapkan itu biasanya dirumuskan dan diterapkan untuk 
Edutech, Tahun 15, Vol.15, No.2, Juni 2016

sesuatu yang relatif baru, ketika khalayak belum memiliki informasi yang memadai mengenainya.

Menurut Soleh Sumirat dan Elvinaro Ardianto (2002), terdapat empat komponen pembentukan citra antara lain :

1. Persepsi, diartikan sebagai hasil pengamatan unsur lingkungan yang dikaitkan dengan suatu proses pemaknaan dengan kata lain. Individu akan memberikan makna terhadap rangsang berdasarkan pengalamannya mengenai rangsang. Kemampuan mempersepsi inilah yang dapat melanjutkan proses pembentukan citra. Persepsi atau pandangan individu akan positif apabila informasi yang diberikan oleh rangsang dapat memenuhi kognisi individu.

2. Kognisi, yaitu suatu keyakinan diri dari individu terhadap stimulus keyakinan ini akan timbul apabila individu harus diberikan informasi-informasi yang cukup dapat mempengaruhi perkembangan kognisinya.

3. Motivasi dan sikap yang ada akan menggerakan respon seperti yang diinginkan oleh pemberi rangsang. Motif adalah keadaan dalam pribadi seseorang yang mendorong keinginan individu untuk melakukan kegiatan-kegiatan tertentu guna mencapai tujuan.

4. Sikap adalah kecenderungan bertindak, berpersepsi, berfikir, dan merasa dalam menghadapi obyek, ide, situasi atau nilai. Sikap bukan prilaku tetapi merupakan kecenderungan untuk berprilaku dengan prilaku tetapi merupakan kecendrungan untuk berprilaku dengan cara-cara tertentu, sikap mempunyai daya pendorong atau motivasi sikap menentukan apakah orang harus pro atau kontra terhadap sesuatu, menentukan apa yang disukai, diharapkan dan diinginkan, sikap mengandung aspek evaluatif artinya mengandung nilai menyenangkan atau tidak menyenangkan, sikap juga diperhitungkan atau diubah. 


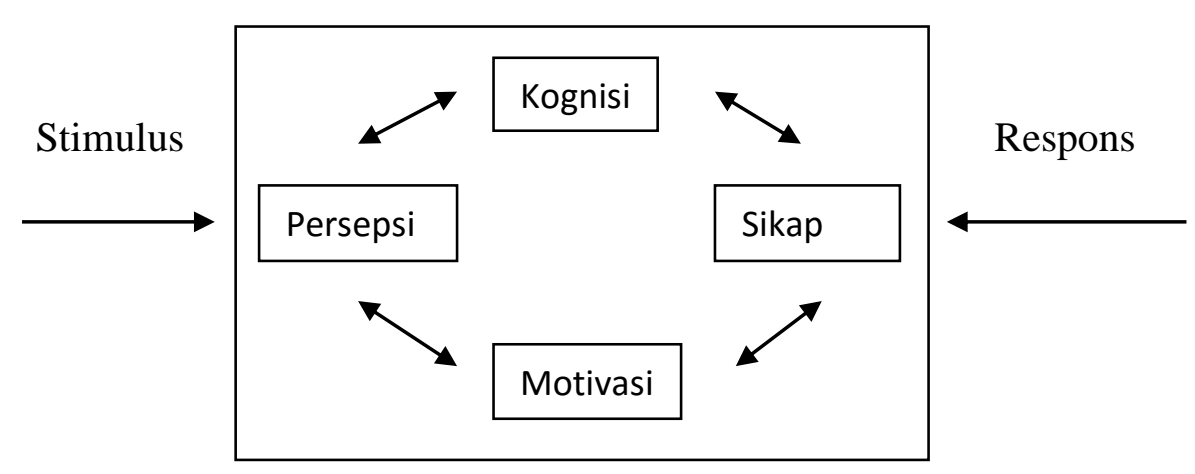

Gambar 1.1

Model Pembentukan Citra

(Soemirat dan Ardianto, 2002:114)

Proses ini menunjukan bagaimana stimulus yang berasal dari luar diorganisasikan dan mempengaruhi respons. Stimulus atau rangsangan yang diberikan pada individu dapat diterima atau ditolak. Jika rangsangan ditolak, maka proses selanjutnya tidak akan berjalan. Hal ini menunjukan bahwa rangsangan tersebut tidak efektif dalam mempengaruhi individu karena tidak adanya perhatian dari individu tersebut.

Sebaliknya, jika rangsangan itu diterima oleh individu, berarti terdapat komunikasi dan perhatian dari organisme, dengan demikian proses selanjutnya dapat berjalan. Begitu pula dengan Public Relations dalam hubungannya dengan publik, haruslah senantiasa mengorganisasi pesan agar stimulus yang ada pada publik akan diterima dengan baik dalam hal ini mencapai citra yang baik. Maka berikut ini terdapat bagan dari orientasi Public Relations, yakni image building (membangun citra).

Berdasarkan penjelasan diatas penulis memahami bahwa Terdapat empat komponen pembentukan citra, yaitu persepsi, kognisi, motivasi dan sikap. Persepsi diartikan sebagai hasil pengamatan unsur lingkungan dimana kemampuan mempersepsi inilah dapat melanjutkan proses pembentukan citra dengan memberikan informasiinformasi kepada individu untuk memunculkan suatu keyakinan. Sehingga dari keyakinan tersebut timbul suatu sikap pro dan kontra tentang produk, dari sikap itulah terbentuknya citra yang positif atau negatif. 
Dramaturgi adalah sandiwara (performance) di hadapan khalayak. kehidupan yang disajikan oleh Sebagai hasil dari minatnya pada manusia. Goffman menyebutnya "pertunjukan" itu, Goffman sebagai bagian depan (front) dan memusatkan perhatian pada dramaturgi bagian belakang (back). Front atau pandangan atas kehidupan sosial mencakup, setting, personal front sebagai serangkaian pertunjukan drama (penampilan diri), expressive yang mirip dengan pertunjukan drama equipment (peralatan untuk di panggung.

mengekspresikan diri). Sedangkan bagian belakang adalah the self, yaitu semua kegiatan yang tersembunyi untuk melengkapi keberhasilan acting atau penampilan diri yang ada pada Front. Berbicara mengenai Dramaturgi Erving Goffman, maka kita tidak boleh luput untuk melihat George Herbert Mead dengan konsep The Self, yang sangat mempengaruhi teori Goffman. Erving Goffman dalam bukunya yang berjudul "The Presentational of Self in Everyday Life" memperkenalkan konsep dramaturgi yang bersifat penampilan teateris. Banyak ahli mengatakan bahwa dramaturginya Goffman ini berada di antara tradisi interaksi simbolik dan fenomenologi.

Kalau kita perhatikan diri kita itu dihadapkan pada tuntutan untuk tidak ragu-ragu melakukan apa yang diharapakan diri kita. Untuk memelihara citra diri yang stabil, orang melakukan

Fokus pendekatan dramaturgis adalah bukan apa yang orang lakukan, bukan apa yang ingin mereka lakukan, atau mengapa mereka melakukan, melainkan bagaimana mereka melakukannya. Berdasarkan pandangan Kenneth Burke bahwa pemahaman yang layak atas perilaku manusia harus bersandar pada tindakan, dramaturgi menekankan dimensi ekspresif/impresif aktivitas manusia. Burke melihat tindakan sebagai konsep dasar dalam dramatisme. Burke memberikan pengertian yang berbeda antara aksi dan gerakan. Aksi terdiri dari tingkah laku yang disengaja dan mempunyai maksud, gerakan adalah perilaku yang mengandung makna dan tidak bertujuan. Masih menurut Burke bahwa seseorang dapat melambangkan simbol-simbol. Seseorang dapat berbicara tentang ucapan-ucapan atau menulis tentang kat-kata, maka bahasa berfungsi sebagai kendaraan untuk 
aksi. Karena adanya kebutuhan sosial masyarakat untuk bekerja sama dalam aksi-aksi mereka, bahasapun membentuk perilaku.

Penelitian ini dirancang sebagai penelitian studi kasus eksploratif. Case Study adalah bentuk penelitian yang mendalam tentang suatu aspek lingkungan sosial termasuk manusia di dalamnya. Case study dapat dilakukan oleh seorang individu, sekelompok individu (misalnya suatu keluarga), segolongan manusia (guru), lingkungan hidup manusia (desa, sector kota) atau lembaga sosial (perkawinanperceraian). Case study dapat mengenai perkembangan sesuatu (misalnya pengaruh didirikannya pabrik di daerah desa), dapat pula memberikan gambaran tentang keadaan yang ada. Bahan untuk case study dapat diperoleh dari sumber-sumber seperti laporan, hasil pengamatan, catatan pribadi, kitab harian, biografi orang yang diselidiki, laporan atau keterangan dari orang yang banyak tahu tentang hal itu (Nasution, 1991:45).

Robert K. Yin (2003:23) membagi penelitian studi kasus menjadi tipe-tipe, yaitu :

1. Studi kasus eksploration, bila studi kasus atau kasus-kasus dipakai untuk memperoleh data atau informasi awal bagi penelitian sosial yang akan dilakukan.

2. Studi kasus eksplanatori, bila sebuah studi kasus atau kasuskasus tertentu yang diteliti tujuannya untuk memberikan pengetahuan sebab akibat.

3. Studi kasus deskriptif, tujuannya untuk memberikan gambaran yang mendalam mengenai srudi kasus, di dalamnya terdapat pemaparan konsep-konsep penelitian.

Berikut ini definisi studi kasus dari beberapa pakar dalam Psikologi dan Bimbingan konseling, yaitu ;

Studi kasus adalah suatu teknik mempelajari seorang individu secara mendalam untuk membantu memperoleh penyesuaian diri yang lebih baik. (Djumhur, 1985). Studi kasus adalah suatu metode untuk mempelajari keadaan dan perkembangan seorang murid secara mendalam dengan tujuan membantu murid untuk mencapai penyesuaian yang lebih baik (Winkel, 1995).

Jadi berdasarkan pembahasan di atas dapat dikatakan bahwa studi kasus adalah suatu studi atau analisa komprehensif dengan menggunakan berbagai teknik.Bahan dan alat 
mengenai gejala atau cirri- Ary, Jacobs, dan Razavieh (1985) ciri/karakteristik berbagai jenis menjelaskan bahwa dalam studi kasus masalah atau tingkah laku hendaknya peneliti berusaha menguji menyimpang, baik individu maupun unit atau individu secara mendalam. kelompok. Analisis ini mencakup Para peneliti berusaha menemukan aspek-aspek kasus seperti jenis, variable yang penting.

keluasan dan kedalaman Berdasarkan batasan tersebut dapat permasalahannya. Latar belakang dipahami bahwa batasan studi kasus masalah (diagnosis) dan latar depan meliputi : (1) sasaran penelitiannya (prognosis), lingkungan dan kondisi dapat berupa manusia, peristiwa, latar individu/ kelompok dan upaya dan dokumen; (2) sasaran-sasaran memotivasi terungkapnya masalah tersebut ditelaah secara mendalam kepada guru pembimbing (konselor) sebagai suatu totalitas sesuai dengan sebagai orang yang mengkaji kasus. latar atau konteksnya masing-masing Data yang telah didapatkan oleh sengan maksud memahami berbagai konselor kemudian diinventaris dan kaitan yang ada di antara variablediolah sedemikian rupa hingga mudah variabelnya. untuk diinterpretasi masalah dan hambatan individu dalam penyesuaian.

Menurut Bogdan dan Bikien (1982) studi kasus merupakan pengujian secara rinci terhadap satu latar atau satu orang subjek atau satu tempat penyimpanan dokumen atau B. HASIL DAN PEMBAHASAN Alasan Pemerintah Kabupaten Purwakarta Melaksanakan Kegiatan

\section{Gempungan}

Kegiatan gempungan diburuan satu peristiwa tertentu. Surachmad (1982) membatsi pendekatan studi kasus sebagai suatu pendekatan dengan memusatkan perhatian pada suatu kasus secara intensif dan rinci. dilakukan pada suatu tempat yang tidak Sementara Yin (1987) memberikan formal, melainkan dilakukan dihalaman batasan yang lebih bersifat teknis rumah warga yang bisa menampung dengan penekanan pada cirri-cirinya. 700-3000 orang. Kegiatan gempungan 
hanya dilaksanakan di desa dan tidak dilakukan untuk daerah perkotaan ataupun kelurahan. Kegiatan ini biasanya diawali dengan pembukaan seremonial oleh Bupati Purwakarta sebagai simbol dibukanya berbagai pelayanan terhadap masyarakat.

Ada beberapa poin penting yang menjadi alasan Bupati Dedi Mulyadi mengadakan kegiatan Gempungan, yaitu:

1. Adanya aspirasi masyarakat yang tidak didengarkan Pemerintah. Mengenai hal ini penulis juga mewawancarai beberapa masyarakat Purwakarta, dan membenarkan bahwa sebelum diangkatnya Dedi Mulyadi menjadi Bupati Purwakarta, banyak aspirasi atau pendapat dari masyarakat yang tidak didengarkan, misalnya seperti yang disampaikan oleh beberapa warga sebagai berikut:

"Bukannya mau
ngejelekin bupati yang
lama ya, tapi
kenyataannya emang
demikian, dulu sebelum
Pak Dedi naik, di
Purwakarta ini bisa
dibilang ngga teratur,
kaya pasar misalnya
sampe makan badan

jalan banyak banget, terus angkot juga gak teratur, dan kita masyarakat punya aspirasi yang kita sampaikan kaya misalnya pasar itu harus bersih, rapi teratur dan aspirasi tersebut baru didengarkan dan jadi kenyataan setelah Pak Dedi jadi Bupati."

2. Kurangnya pengetahuan dari Pemerintah mengenai kebutuhankebutuhan serta masalah yang dihadapi masyarakat. Berkaitan dengan hal tersebut, beberapa masyarakat yang diwawancarai penulis menyatakan sebagai berikut:

"Sebelum ada
gempungan dari Pak
Dedi, kita warga kecil
ini seringkali bingung
neng kalo mau ngadu
atau sekedar ngusulin
sesuatu ke Pemkab,
istilahnya kan kita
yang tau persis di
daerah kita ada
masalah apa,
katakanlah masalah
air bersih, atau
masalah listrik dan
sebagainya. Dulu itu
Pemerintah apalagi
Bupatinya bisa
diitung jari deh mau
dateng kesini, dan
karena adanya batas
tersebut kita warga
kecil juga jadi takut
dan males sama


Pemerintah. Tapi
sejak Pak Dedi naik, beliau ngga segan turun kesini, ngobrol sama kita-kita dan masalah apapun yang kita rundingkan pasti dicarikan jalan keluar secepatnya."

Sisi lain dari program gempungan, adalah pentingnya mempersiapkan generasi muda sebagai pewaris kehidupan ini yang siap mental dan siap secara ekonomi. Agar kedepan, Negara bisa dibangun oleh perantiperanti ekonomi rakyat yang mapan dan piranti etos kerja yang tinggi. Kegiatan gempungan ini merupakan bentuk nyata dari tindakan sosial sebagaimana Max Weber lebih lanjut oleh Schutz dinyatakan berorientasi pada perilaku orang atau orang lain pada masa lalu, sekarang dan akan datang.

Terlihat disini bahwa pencitraan yang dibangun oleh H. Dedi Mulyadi, selaku Bupati Purwakarta, berawal dari program-program yang dibuat untuk masa jabatannya, yang salah satunya adalah gempungan ini. Dimana masyarakat Purwakarta sendiri sudah mulai menyadari bahwa pentingnya adat Sunda yang sudah cukup lama ditinggalkan. Dedi Mulyadi, membangunnya dengan mengambil beberapa kegiatan-kegiatan adat Sunda yang berdampak cukup besar untuk Purwakarta itu sendiri dan juga untuk penilaian terhadap Dedi Mulyadi sendiri. Dengan adanya program gempungan ini, masyarakat Purwakarta menjadi lebih sering untuk saling berkomunikasi dengan pejabat pemerintah setempat dan tidak hanya itu, masyarakat Purwakarta pun diberikan hiburan sekaligus solusi untuk keluh kesahnya selama ini tentang kota Purwakarta. Hal ini tentunya bertujuan untuk meninggalkan kesan yang baik pada rakyat Purwakarta sendiri dan memuluskan jalan mencapai tujuan bersama. Dengan konsep gempungan ini terciptalah suasana-suasana dan kondisi interaksi yang kemudian memberikan makna tersendiri.

Berkaitan dengan citra positif yang didapatkan Dedi Mulyadi dari warga Purwakarta, terdapat empat komponen pembentukan citra, yaitu persepsi, kognisi, motivasi dan sikap. Persepsi diartikan sebagai hasil pengamatan unsur lingkungan dimana kemampuan mempersepsi inilah dapat melanjutkan proses pembentukan citra dengan memberikan informasi-informasi 
kepada individu untuk memunculkan suatu keyakinan. Sehingga dari keyakinan tersebut timbul suatu sikap pro dan kontra tentang produk, dari sikap itulah terbentuknya citra yang positif atau negatif.

Makna Kegiatan Gempungan bagi Masyarakat Purwakarta

\section{Mendekatkan Diri Pada Masyarakat}

Begitu banyak sebenarnya manfaat yang didapatkan oleh masyarakat dengan adanya kegiatan Gempungan. Dan masyarakat lebih memaknai kegiatan Gempungan ini sebagai sebuah cara yang efektif terutama bagi pemerintah Purwakarta untuk mendekatkan diri dengan masyarakatnya, mengetahui apa saja kendala dan permasalahan yang dihadapi oleh masyarakat, dan mencarikan solusi yang paling tepat agar masyarakat bisa hidup lebih sejahtera dibandingkan sebelumnya.

Seperti yang disampaikan oleh Bapak Endang Syaifudin yang diwawancarai penulis sebagai berikut:

$\begin{array}{lr}\text { "Menurut saya } & \text { mah } \\ \text { gempungan } & \text { ini } \\ \text { tujuannya } & \text { untuk } \\ \text { memudahkan } & \end{array}$

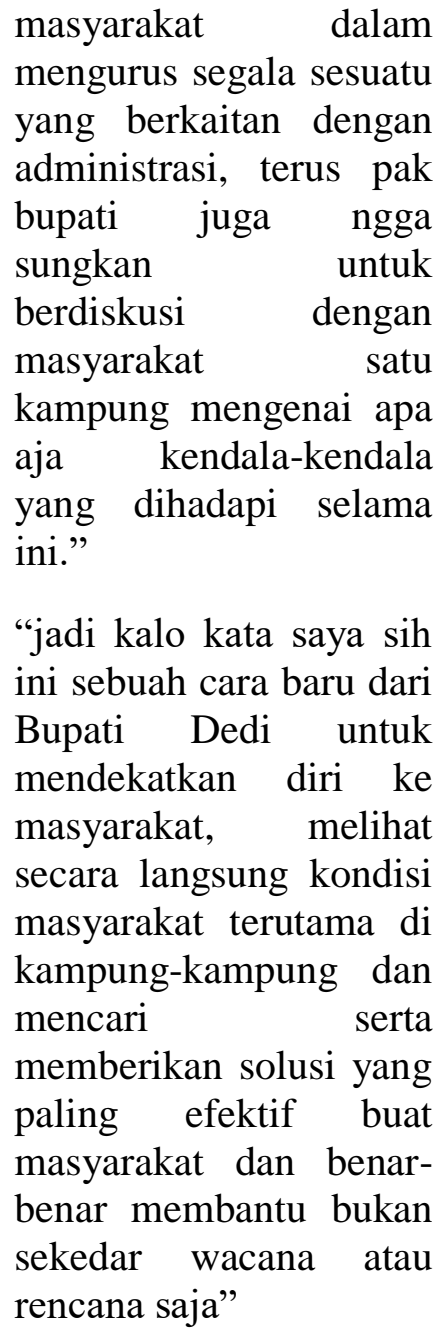

\section{Wujud Kesukseskan Bupati}

Dengan diadakannya kegiatan Gempungan, masyarakat Purwakarta pun memandang Dedi Mulyadi sebagai salah satu Bupati tersukses yang pernah memerintah di Purwakarta, beberapa tokoh masyarakat yang sempat diwawancarai penulis menyatakan sebagai berikut:

"Kita harus mengakui sejak Bapak Dedi Mulyadi memerintah jadi Bupati disini, warga benar-benar merasakan 
perubahan positif yang jauh sekali dan belum pernah dirasakan sebelumnya. contoh kecilnya aja seperti KTP atau KK, sekarang di RW saya aja sudah semua orang punya KTP dan KK, padahal dulu sebelum ada Gempungan, paling hanya sekitar 20 sampai $30 \%$ saja yang punya dan mau ngurus KTP sama KK, yang kaya gini kan sebenarnya bukti bahwa masyarakat itu mau ngurus administrasi selama dipersuasi dengan baik dan tidak dipersulit dalam prosesnya."

"Wah sangat bersyukur mbak, Bupati kita Dedi Mulyadi, walaupun ada berita-berita miring tentang beliau, tapi menurut saya berita itu ngga ada yang bener dan cuma cara curang dari segelintir golongan yang iri dengan keberhasilan Bapak Dedi memerintah disini. Buktinya udah 2 periode jadi Bupati dan hampir tidak pernah dengar ada warga yang menjerit minta Bupati diganti dengan orang lain, justru yang saya sering dengar adalah bagaimana warga itu sangat senang karena Bupatinya adalah Dedi Mulyadi."
Dari kedua hasil wawancara diatas terlihat jelas bahwa baik tokoh masyarakat secara khusus, maupun masyarakat Purwakarta secara umum, menganggap Dedi Mulyadi sebagai Bupati terbaik yang pernah dimiliki Purwakarta. Visi dan misi serta berbagai kegiatan kemasyarakatan yang dilakukan oleh Dedi Mulyadi membuat masyarakat merasa senang dan nyaman. Mereka juga menganggap bahwa Dedi Mulyadi merupakan sosok pemimpin yang benar-benar memerdulikan kesejahteraan rakyat dan bukan sekedar wacana belaka. Berbagai gebrakan yang dilakukan oleh Dedi Mulyadi meskipun sempat mendapatkan kontra dari beberapa pihak, namun ternyata sangat berhasil dan merubah Purwakarta sebagai daerah yang memiliki banyak prestasi baik dalam hal kebudayaan, maupun kependudukan.

\section{Pola Komunikasi Pemkab Purwakarta dengan Masyarakat dalam Kegiatan Gempungan}

Dalam berkomunikasi dengan rakyatnya pada kegiatan Gempungan ini, Dedi Mulyadi melaksanakan program yang hampir sama dengan kegiatan blusukan seperti yang Jokowi 
laksanakan di Jakarta. Namun melawak diatas panggung atau pun Gempungan memiliki keunikan bernyanyi.

tersendiri karena berbeda dengan program blusukan, kegiatan kunjungan ke masyarakat tersebut tidak hanya dilakukan melalui proses diskusi langsung dengan masyarakat pada saat Bupati dan aparat Pemkab melakukan kegiatan administrasi kependudukan di lapangan, tapi juga dikemas dalam sebuah acara hiburan rakyat khas Sunda yang disebut dengan gempungan.

Sebagai sarana komunikasi, dalam kegiatan gempungan yang diakhiri dengan acara ngahajatan urang lembur yang di dalamnya dipertontonkan juga beberapa Kawih Sunda sangat berguna untuk menyebarluaskan informasi secara massal dan cepat. Konten dari kawih sunda dalam kegiatan gempungan ini nyanyian dalam bahasa daerah (Sunda) yang menceritakan tentang topik tertentu yang telah disesuaikan dengan tema acara tersebut dan kemudian dilanjutkan dengan lawakan yang menggunakan bahasa Sunda atau yang biasa disebut dengan bodoran. Hampir disetiap kesempatan, sang Bupati Purwakarta selalu ikut mengisi acara tersebut dengan ikut

Oleh karena itu sebagian warga masyarakat, menganggap kegatan ini sebagai acara hiburan dan tidak terlalu memahami dengan isi lirik dari Kawih Sunda yang disajikan. Pada penelitian ini, penulis menjumpai salah satu informan yang menuturkan bahwa program gempungan hanya sekedar hiburan gratis yang dilaksanakan oleh pemerintah (Pemda Kab. Purwakarta). Informan yang berprofesi sebagai Ibu Rumah Tangga (IRT) menyampaikan hal sebagai berikut:

"Saya sih lihatnya acara
itu (gempungan) emang
acara hiburan gratis
aja...Nyanyiannya
(Kawih Sunda) juga
saya kurang paham apa
maksudnya. Lumayan
lah ada hiburan gratis
buat orang desa,
daripada bosen ga ada
hiburan lain"

Manifestasi budaya leluhur berupa kawih sunda yang dilaksanakan oleh Bupati Purwakarta mendapatkan respon positif dari warga Purwakarta. Salah satu informan, seorang mahasiswa tingkat akhir di salah satu Perguruan Tinggi Swasta di Purwakarta menyampaikan bahwa Bupati 
Purwakarta mempunyai perhatian yang cukup besar terhadap budaya leluhur.

"Kayanya dari acara Gempungan juga Pak Bupati memang punya concern yang cukup besar sama budaya lokal (Sunda). Kadang pas Kawih Sunda dimaenkan, Pak Bupati juga suka ikut menyanyikannya. Jadi kalo saya bilang sih....dia (Bupati) punya citra yang positif tentang perhatiannya tentang budaya daerah. Saya juga ingat pernah ada satu kawih yang liriknya kurang lebih bilang kalo jadi pempimpin itu harus bisa lihat apa yang ada dibawah.....artinya dari lirik itu juga yang mau disampaikan adalah Pak Bupati selalu memperhatikan kondisi rakyatnya, makanya di tiap acara Gempungan Pak Bupati selalu hadir supaya bisa tahu apa sih yang sebenarnya rakyatnya

butuhkan....kalo kata saya disitulah citra Bupati sebagai abdi masyarakat dapet banget."

Acara "ngahajatan urang lembur" yang diprakarsai oleh Dedi Mulyadi benar-benar bisa menjadi wadah kreativitas orang Purwakarta. Dedi Mulyadi selaku Bupati Purwakarta pun selalu turut andil dalam acara ini, alasannya seperti yang diungkapkan oleh Nurfalah selaku Kasubag Protokol Pemkab Purwakarta sebagai berikut:

"Bisa dibilang bahwa Bapak (Dedi Mulyadi, red.) merupakan pelopor kegiatan - kegiatan yang benar-benar melibatkan masyarakat.

Gempungan, sampai ngahajatan urang lembur merupakan beberapa contoh dimana Bapak menunjukkan rasa cintanya kepada Purwakarta dan khususnya kepada setiap warga Purwakarta. Beliau pun tidak Cuma memberikan konsep semata, bahkan dari awal penyusunan kegiatan ini, susunan acaranya, budaya apa saja yang dilibatkan, sampai rundown acara pun merupakan ide dari beliau. Jadi menurut kami, Bapak ingin memperlihatkan kepada Indonesia, Asia bahkan dunia bahwa Purwakarta meskipun masih Kabupaten tapi memiliki unsur budaya dan kekompakan warga yang tidak kalah dibandingkan kota-kota besar."

Pendapat senada juga disampaikan oleh Azis Kamran selaku Kasubag 
Peliputan dan Dokumentasi serta Jaya Pranolo selaku Kasubag Pemberitaan Pemkab Purwakarta sebagai berikut:

"Terus terang saya juga ga pernah nyangka Bapak memiliki ide cemerlang seperti ini, mbak juga saya yakin belum tentu punya perkiraan kalo Bapak Bupati punya konsep Gempungan sama Ngahajatan Urang Lembur kan ya. Disini kami jajaran aparat Pemkab sangat mengapresiasi ide-ide baru dari Bapak, apalagi kalo ide tersebut mencirikan budaya Sunda, dan Bapak pun ngga pernah sekedar ngomong doang, tapi selalu ikut terlibat di dalamnya. Menurut saya ini mungkin karena beliau orang Sunda asli dan cinta akan budaya Sunda, liat aja udah berapa banyak lagu dan puisi yang beliau ciptakan sendiri."

Beberapa pendapat informan yang juga merupakan pegawai Pemkab Purwakarta menegaskan bahwa kegiatan Gempungan maupun Ngahajatan urang Lembur merupakan ide orisinil dari sang Bupati Dedi Mulyadi ini sendiri. Penulis sendiri mengalami transformasi ide tentang Budaya Sunda di Purwakarta dari waktu ke waktu, yaitu sebelum dan sesudah pemerintahan Dedi Mulyadi, sangat mengalami perubahan yang signifikan, mulai dari infrastruktur yang semakin membaik, sampai dengan kebudayaan Sunda yang semakin lama semakin mengental dan membuat penduduk Purwakarta secara otomatis jadi mengetahui dan mencintai budaya mereka sendiri.

$$
\text { Erving Goffman }
$$

menyatakan bahwa hukum interaksi sosial bisa ditemukan pada hukum panggung (stage) atau individu yang memainkan peran pada penampilan teater atau drama pertunjukan (Susilo, 2008:368). Menurut Goffman, perilaku orang dalam interaksi sosial selalu memainkan peran informasi agar orang lain mempunyai kesan lebih baik. Goffman mengasumsikan bahwa ketika orang berinteraksi, mereka ingin menyajikan suatu gambaran diri yang diterima orang lain. Dia menyebut upaya tersebut sebagai impression management atau pengelolaan kesan, yaitu teknik yang digunakan aktor untuk memupuk kesan tertentu dan situasi tertentu untuk mencapai tujuan tertentu. Dalam hal ini, Bupati 
Purwakarta mengarah kepada membentuk makna subjektif. Makna konstruksi realitas yang dibangun oleh subjektif ini diartikan sebagai tindakan Pemerintah Daerah terhadap sosial yang berorientasi pada perilaku masyarakat untuk menginternalisasi orang lain pada masa lalu, sekarang nilai-nilai luhur budaya daerah. Sehingga pembangunan Purwakarta diwarnai dengan pembangunan fasilitas publik yang bernuansa budaya Sunda.

Menurut prespektif Edward T.Hall (1976), masyarakat Indonesia dan Asia pada umumnya termasuk dalam masyarakat yang berbudaya konteks tinggi (high context culture). Dalam budaya konteks tinggi, makna terinternalisasikan kepada orang yang bersangkutan dan pesan nonverbal lebih ditekankan. Kolektivisme ditandai dengan ketidakjelasan tujuan pribadi dari tujuan kelompok. Tujuan pribadi harus mengalah pada tujuan kelompok, manusia kolektivis percaya bahwa untuk bertahan hidup, mereka bergantung pada kelompok, bukan pada diri sendiri. (Kurnia, 2010: 16)

Komunikasi Bupati Purwakarta dalam bentuk kegiatan Kawih Sunda merupakan salah satu bentuk tindakan sosial. Konsep sosial didefinisikan sebagai hubungan antara dua orang atau lebih. Sedangkan konsep tindakan didefinisikan sebagai perilaku yang dan akan datang.

Sesuai dengan pembahasan teori tindakan sosial tersebut, pertunjukkan Kawih Sunda dalam kegiatan gempungan yang digagas oleh Dedi Mulyadi merupakan tindakan sosial yang bertujuan untuk berkomunikasi, berinteraksi, serta menanamkan citra dirinya kepada masyarakat.

Kemudian berkaitan dengan teori interaksi simbolik yang juga digunakan dalam penelitian ini, perilaku manusia harus dilihat sebagai proses yang memungkinkan manusia membentuk dan mengatur perilakunya dengan mempertimbangkan ekspektasi orang lain yang menjadi mitra interaksi yang berada di lingkungan sosial yang sama. Penganut interaksionisme simbolik percaya bahwa perilaku manusia adalah produk dari interpretasi mereka atas dunia di sekeliling mereka, jadi tidak mengakui perilaku dipelajari atau ditentukan. Kegiatan Gempungan yang dilakukan oleh Bupati Dedi Mulyadi merupakan sebuah cara yang memberikan kesempatan kepada 
masyarakat untuk membiarkan mereka berbicara dan berperilaku apa adanya sebagaimana yang mereka kehendaki, dan hal tersebut kemudian tercermin dalam aspirasi-aspirasi yang disampaikan oleh masyarakat kepada Bupati dan aparat Pemkab Purwakarta.

Sesuai dengan premis yang disampaikan oleh Blumer (dalam Poloma, 2000) bahwa dalam interaksionisme simbolik, tindakan manusia akan berdasarkan maknamakna yang ada pada sesuatu yang mendasari tindakan tersebut. Dalam hal ini tindakan tersebut merupakan pandangan atau persepsi masyarakat Purwakarta terhadap Dedi Mulyadi sebagai Bupati, dimana menurut masyarakat bahwa Dedi Mulyadi benar-benar bisa membawa dampak yang positif bagi kesejahteraan masyarakat Purwakarta terutama setelah adanya kegiatan Gempungan. Jadi disini terlihat jelas bahwa perilaku masyarakat Purwakarta yang menghormati dan menghargai Dedi Mulyadi merupakan produk dari interpretasi masyarakat atas kegiatan Gempungan yang dilakukan Dedi Mulyadi.

\section{SIMPULAN}

Berdasarkan hasil penelitian yang dijelaskan pada bab sebelumnya, maka dapat diambil beberapa simpulan yaitu Alasan Pemerintah Kabupaten Purwakarta yang dipimpin oleh Bupati Dedi Mulyadi membuat sebuah kegiatan yang dinamakan dengan Gempungan dikarenakan pada pemerintahan sebelumnya, masih ada aspirasi masyarakat yang tidak diperhatikan dan diakomodir oleh Pemerintah, selain itu Bupati Dedi Mulyadi juga menganggap bahwa Pemkab Purwakarta masih memiliki pengetahuan yang kurang mengenai kebutuhan-kebutuhan serta masalahmasalah apa saja yang sebenarnya sedang dihadapi oleh masyarakat Purwakarta. Alasan yang ketiga adalah karena Bupati Dedi Mulyadi menganggap banyaknya anggaran APBD Kabupaten Purwakarta yang disia-siakan karena program-program Pemerintah sebelumnya yang sebenarnya kurang dibutuhkan oleh masyarakat, sehingga pada akhirnya program pemerintah tersebut menjadi tidak efektif dan hanya membuang APBD yang seharusnya bisa dimanfaatkan lebih efektif lagi. 
Kegiatan Gempungan yang dilakukan melalui proses diskusi diprakarsai oleh Dedi Mulyadi selaku langsung dengan masyarakat pada saat Bupati Purwakarta memiliki makna Bupati dan aparat Pemkab melakukan yang mendalam bagi masyarakat, kegiatan administrasi kependudukan di hampir semua masyarakat menyatakan lapangan, tapi juga dikemas dalam bahwa mereka sangat terbantu dengan sebuah acara hiburan rakyat khas adanya kegiatan Gempungan ini. Sunda yang disebut dengan gempungan Masyarakat juga berpendapat bahwa di buruan urang lembur. Melalui acara melalui kegiatan Gempungan, Bupati hiburan yang diadakan pada malam dan Pemkab Purwakarta dapat lebih hari ini, Dedi Mulyadi selaku Bupati mengetahui secara pasti apa-apa saja selalu tampil dihadapan masyarakat yang memang diperlukan dan diangap Purwakarta dan pada kesempatan itu darurat oleh masyarakat Purwakarta. beliau selalu menyampaikan berbagai Beberapa kegiatan yang dianggap hal penting yang berkaitan dengan benar-benar membantu masyarakat kondisi masyarakat, kebijakan seperti administrasi kependudukan pemerintah sampai dengan hal-hal yaitu pembuatan KTP, KK dan akta sosial lain yang berada dalam ruang kelahiran, kemudian kegiatan donor lingkup Purwakarta, dan disinilah darah, sampai dengan bantuan berupa masyarakat dianggap dapat lebih ternak yang diharapkan benar-benar mudah memahami pesan - pesan dari bisa mendongkrak kesejahteraan masyarakat.

Bupati Dedi Mulyadi.

Adapun saran yang dari hasil

Dalam berkomunikasi dengan penelitian ini, Pemkab Purwakarta rakyatnya pada kegiatan Gempungan ini, Dedi Mulyadi melaksanakan program yang hampir sama dengan kegiatan blusukan seperti yang Jokowi laksanakan di Jakarta. Namun sebaiknya bisa meneruskan konsep kegiatan Gempungan ini meskipun tanpa Dedi Mulyadi sebagai Bupati. Karena bagaimanapun juga kegiatan Gempungan memiliki keunikan tersendiri karena berbeda dengan program blusukan, kegiatan kunjungan Gempungan ini terbukti bisa sangat membantu masyarakat dalam berbagai aspek

Masyarakat Purwakarta sebaiknya ke masyarakat tersebut tidak hanya bisa bersikap lebih terbuka dan lebih 
mengapresiasi ide-ide Bupati dalam kegiatan Gempungan ini, karena Bupati sebagai pemrakarsa kegiatan Gempungan harus diakui tidak bisa seterusnya mengawasi berlangsungnya kegiatan ini.

\section{DAFTAR PUSTAKA}

Ardianto, Elvinaro. (2007). Komunikasi Massa Suatu Pengantar. Bandung : Simbosa Rekatama Media

$$
\text { . (2011). Handbook }
$$

Of Public Relations: Pengantar Komprehensif. Bandung:

Simbiosa Rekatama Media

Berger Peter L. \& Thomas Luckman. (1990). The Sosial Construction of Reality, A Treatise in the Sociological of Knowledge

Cuff, E.C \& G.C.F. Payne. (1981). Perspectives in Sociology. London; George Allen

Cutlip, Scott M, Center, Allen H. (2009). Effective Public Relations. Edisi kesembilan. Jakarta: Kencana

Djuarsa, Sendjadja S. (1994). Teori Komunikasi. Jakarta: Universitas Terbuka

Effendy, Onong Uchjana. (1997). Ilmu Komunikasi Teori dan Praktek. Cetakan Ke-sepuluh. Bandung : PT. Remaja Rosdakarya
Fisher, B. Aubrey. (1986). Teori-teori komunikasi, Bandung: CV Alfabeta

Jefkins, Frank. (2003). Public Relations. Jakarta: PT. Erlangga

Kartono, Kartini \& Gulo, Dali. (2000). Kamus Psikologi. Bandung: CV. Pionir

Moleong, Lexy. (2002). Metodologi Penelitian Kualitatif. Bandung: PT.Remaja Rosdakarya

Mulyana, Deddy. (2002). Metode Penelitian Kualitatif. Bandung : Remaja. Rosdakarya

(2004). Ilmu Komunikasi, Suatu Pengantar. Bandung : PT. Remaja Rosdakarya

Nasution, S. (1991). Metode Penelitian Naturalistik Kualitatif, Bandung : Tarsito

Poloma, Margaret M. (2000). Sosiologi Kontemporer, Raja grafindo Persada

Purwanto, Joko. (2006). Komunikasi Bisnis, Jakarta: Edisi Kedua, Erlangga

Rakhmat, Jalalludin. (2007). Metode Penelitian Komunikasi. Bandung: Remaja Rosda Karya

Ruslan, Rosady. (2010). Manajemen Public Relations \& Media Komunikasi. Jakarta: PT Raja Grafindo 
(2002). Kiat \& Winkel, W.S. (1993). Psikologi Strategi Kampanye Public Pendidikan dan Evaluasi Belajar. Relations. Jakarta: PT. Jakarta: Gramedia Pustaka

RajaGrafindo Persada

Yin, Robert K. (2003). Studi Kasus:

Soemirat, Soleh \& Elvinaro Ardianto. Disain dan Metode. M. Djauzi (2002). Dasar-Dasar Public Mudjakir. (Penerjemah). Jakarta: Relations. Bandung: PT. Remaja PT. Raja Grafindo Persada Rosdakarya

Subagyo, P. Joko. (2006). Metode Penelitian Dalam Teori Dan Praktek. Penerbit Rineka Cipta

Sunarto. (1993). Pengantar Sosiologi, Jakarta, Lembaga Penerbit FE UI 